\title{
Sociological Analysis of the Dialectal Political/Social Discourse in the USA
}

\author{
Steven Gerardi \\ Professor Emeritus of Sociology, New York City College of Technology, CUNY, New York, USA \\ Email: Tutti50wag@aol.com
}

How to cite this paper: Gerardi, S. (2019). Sociological Analysis of the Dialectal Political/Social Discourse in the USA. Sociology Mind, 9, 127-129.

https://doi.org/10.4236/sm.2019.91008

Received: December 12, 2018

Accepted: January 8, 2019

Published: January 14, 2019

Copyright (C) 2019 by author(s) and Scientific Research Publishing Inc. This work is licensed under the Creative Commons Attribution International License (CC BY 4.0).

http://creativecommons.org/licenses/by/4.0/

\begin{abstract}
This effort provides a sociological analysis of the current social/political dichotomy in the United States of America (USA). This analysis will be drawn from two opposing sociological theorist, Talcott Parsons (Functionalism), and Raf Dahrendorf (Conflict View).
\end{abstract}

\section{Keywords}

Functionalism, Conflict View, Parsons, Dahrendorf, Roe V. Wade

\section{Introduction}

This original effort will provide a Sociological Analysis of Social/political background by contrasting two polar opposite views of the forces of Social Change in the USA today. This effort will begin with Parsons conservative theory of Functionalism, contrasted by Dahrendrof s "Conflict View" a Marxist paradigm on social change.

\section{Theorical Concepts}

Parsons defined Functionalism as the social system parts of society (family, education, the economy so on) are structured to maintain (in the USA) social/political equilibrium. When a social system part is dysfunctional (not maintaining social/political balance), all other social system parts associated with the dysfunctional part, will also become dysfunctional (a dysfunctional family will affect education, crime, employment, health so on).

Parsons identified four analytical concepts for interpretation and comparative study of Functionalism in the USA, known as AGIL scheme, or "pattern variables". The AGIL scheme consists of Adaptation Cell, Goal Attainment Cell, Integration Cell and Latency Cell. 
The Adaptation Cell has the instrumental actions and values toward the means, selection and conviction in adapting to the social environment. Intrinsic to this cell is the concept of social homeostasis. Parsons argued that biological entities are always interacting and adapting to the natural environment. Likewise, social actors should be interacting, and adapting to the changing social environment.

The Goal Attainment Cell has those consummatory needs necessary for the expressive symbolic social requirement for balanced social change with the acceptance of the "out group", Technology, dress, housing, education and so on.

The Integration Cell contains the ability and willingness to integrate, indeed the responsibility to identify with the social system (i.e. system membership).

The Latency Cell contains the normative commitment for harmonious social/political change; 1) the "out group"; and 2) innovations in science, education and technology. The key to social change is the institutionalization and generalization of values, and norms culminating in the universality and generalization of beliefs. Thereby narrowing the gap between the different cultures, and skill-sets, resulting in social harmony (Gerardi, 2010b).

\section{Conflict Paradigm}

Raf Dahrendorf argued that social systems are based in hierarchies of power, and social status (race, age, gender, and class). These hierarchies are always in conflict and opposing one another for what they conceive to be "scarce resources" (such as power, authority, wealth, health care, education employment and housing). Hence, social conflict is an ever-present feature. Therefore, progress is conflict and conflict is progress, (since once a solution is uncovered from a set of conflicts, a new series of conflicts arise, new solutions, and so on (Gerardi, 2010a).

\section{Theorical Application/Discussion}

The USA today can be viewed as a tale of two social/political philosophies. On the one hand, approximately half of the population falls into the social/political agreement and consensus view (Parsons). On the other hand, the second half falls into the social conflict view (Dahrendorf).

A case in point is the continuous civil rights debate over Roe $\mathrm{V}$ Wade a landmark decision issued by the United States Supreme Court on the issue of the constitutionality of laws that criminalized and restricts access to abortions. This ruling, extended to woman the right to seek an abortion, thereby extending reproductive rights to all woman.

Over the past 45 years Roe v. Wade has been controversial because of the moral and religious, implications associated with abortion. The Roe V. Wade controversy can be seen through two social prisms: 1) Pro-choice; and 2) Pro-life.

The Pro-choice Social group argues that the decision to abort a pregnancy is 
that of the mothers, and not the state. Moreover, without this Court Ruling, woman will still not have the right to control their reproductive system. Reproductive rights rest on the recognition of the basic right of women to decide freely and responsibly the number, spacing and timing of their children. Moreover, Roe. V. Wade is necessary in order to provide woman the right of reproduction freedom, thus further advancing the civil rights movement, and best health rights in the USA through conflict/solution.

The Pro-life Social Group continues to call for the repeal of Roe. V. Wade suggesting that the abortion issue should have come to a popular consensus and agreement for acceptance; rather than the Supreme Court creating conflict over this issue. This social group also suggests that life begins at conception, hence concern with the sanctity of life. Moreover, no civilized society intentionally takes the life of the unborn, abortion should never be used as a form of birth control (Marian Faux, 2001).

\section{Conclusions}

The social/political dichotomy in the USA has created a Culture War. A Culture War refers to the conflict between traditionalist, classical, liberal, and values concerning: 1) science, 2) history, 3) educational, 4) curricula, 5) health care, 6) general social issues and abortion (Florina, Abrams \& Pope, 2006). This Culture War can be seen in the political/ideology found in the two-party system (Democrats/Republicans) today.

Lastly, it should be noted that this effort made no suggesting or alluded to favoring or indorsing one concept over the other; rather this effort was an objective sociological analysis of the social/political discourse in the USA today.

\section{Conflicts of Interest}

The author declares no conflicts of interest regarding the publication of this paper.

\section{References}

Florina, Abrams \& Pope (2006). Culture War? The Meth of a Polarized America (2nd ed.). Pearson.

Gerardi, S. (2010a). A Brief Survey of the Sociological Imagination (3rd ed.). Kendall/Hunt Publishing Company.

Gerardi, S. (2010b). Functionalism 2.0-Rethinking an America Tradition of Conservative Thought. The Socjournal.

Marian Faux Roe v. Wade (2001). The Untold Story of the Landmark Supreme Court Decision that Made Abortion Legal Updated Edition, National Book Network. 